\title{
Multitheoretical Communication Framework of Slang Language: A Case Study toward Interpretation and The Use of Anjay in Indonesia
}

\author{
Arina Rohmatul Hidayah ${ }^{1}$ \\ ${ }^{1}$ Institut Agama Islam Tribakti Kediri \\ 1arinarohmatulh@gmail.com
}

\begin{abstract}
This research was conducted with the aim of discussing an issue that is currently viral on social media in Indonesia, namely the prohibition of using the word of anjay as slang language. The lack of research based on theoretical exploration of slang is a component that needs to be completed. So in this case, the researcher puts forward a multitheoretical framework, especially with regard to communication theories, where one of the components of the study also involves problems of language, structure and function in society. Through the case study method, the researcher selected 5 informants who understood and had used the word of anjay. Finally, with in-depth interview, there are many aspects that can be explored from the word of anjay and there are several relevant theories to explain these aspects.
\end{abstract}

Keywords: Communication Theory, Multitheoretical Framework, Slang language, Anjay, Indonesia

\section{Introduction}

Recently, a discussion that is currently viral in Indonesia has emerged, namely the prohibition of using the word anjay. This prohibition appeared after Lutfi Agizal uploaded content on Youtube. According to him, this word is not good to use in the association of the younger generation because it has a negative meaning and can damage the nation's morals ${ }^{1}$. In connection with this incident, the National Commission for Child Protection finally issued a release requesting that the use of anjay not be used in social language. The use of anjay in a negative connotation has the potential to be punished ${ }^{2}$. The ban has reaped pros and cons among the community.

On the one hand there are linguists who interpret that anjay comes from the word dog which has a negative connotation. A linguistic expert from Gadjah Mada University (UGM), I Dewa Putu Wijana, views that this ban was issued, because he saw the real meaning of anjay is a dog which means curse $^{3}$. But on the other hand, many people interpret the opposite. There are some people who think that the word is an expression of

1 Abas, D. Lutfi Agizal Kaget Dibujat Warganet karena Pelopori Larangan Kata "Anjay". Medcom. Retrieved on 2 September 2020 from

https://m.medcom.id/hiburan/selebritas/yKXAaZDN-lutfi-agizal-kaget-dihujat-karena-peloporilarangan-kata-anjay.

${ }^{2}$ Abas, D.

3 Azanella, L. A. (2020, August 31). Larangan Penggunaan "Anjay”, Reaksi Netizen, dan Kata Abli Bahasa. Kompas. Retrieved on 31 August 2020 from

https://www.kompas.com/tren/read/2020/08/31/081829965/larangan-penggunaan-anjay-reaksinetizen-dan-kata-ahli-bahasa?page=all\#page2

Jurnal Kopis: Kajian Penelitian dan Pemikiran Komunikasi Penyiaran Islam

Volume 03, issue 02, Februari 2021 
admiration for something. Indeed, there is no definite definition regarding the word of anjay. Even the Big Indonesian Dictionary has not clearly interpreted this. What is there is anjir which means canal, channel (water) or canal. Don't know who coined the word, when and in what context. Because of this, many people put anjay into the slang language. According to Thorne (2009), slang language is deliberately chosen because of its striking informality and is consciously used in preference to "appropriate" speech. Strengthened by the opinion of Eble in Hudson (1996), slang language is a collection of everyday words and phrases, always changing that are used by speakers to build or strengthen identity or cohesiveness in a group or with trends or fashion in society at large $e^{4}$.

Thus, the informality of anjay, inviting researchers to explore various aspects related to the word. Through a qualitative descriptive method, Trimastuti examines the use of alay in social media in terms of sociolinguistic theory. The conclusion of this study is that the use of alay can only be understood by certain groups who use the language. In relation to sociolinguistic theory, this theory describes the relationship between language and society, how a person speaks differently in different social contexts. From this research, the most explored aspect is with whom and in what context the word of alay is used. Other aspects such as the construction of the meaning, the motivation or purpose of using the word and its impact on the communication process have not been widely discussed ${ }^{5}$.

There is also research from Pradianti which examines the use of slang language among high school students in Bandung. The slang language here includes a variety of words that are often used by students. By using the qualitative descriptive method the conclusions are obtained, the use of slang language has the aim of saying something easily, the students want to express their anger, confuse other friends and break the ice to make it more fun. In addition, each student has their own slang language to mark their identity in the conversation process ${ }^{6}$. This research is interesting because it shows how slang language can strengthen a person's identity in society. But on the other hand, the theoretical discussion is still weak, because researchers have not linked the relevant theory to the phenomenon.

Rezeki, et al also examined the use of slang language among young people. In their explanation, they revealed that there were three points discussed, namely the types of slang used by the millennial generation on social media, how is the interpretation and why the millennial generation uses this language. From the results of research using qualitative descriptive methods, it was found that of the 40 UINSU students, 33 of them used slang language on Facebook and 31 used it on Instagram. As for the types of languages used are fresh and creative, flippant, imitative, acronym and clipping. And finally, the reason students use the language is to say hello, start casual conversations, express impressions, and show intimacy ${ }^{7}$. Although it can identify slang using semantic analysis, some things that

\footnotetext{
4 Trimastuti, W. (2017). An Analysis of Slang Words Used in Social Media. Jurnal Dimensi Pendidikan dan Pembelajaran, 5 (2), 64-68. Retrieved on 20 August 2020 from

http://journal.umpo.ac.id/index.php/dimensi/article/view/497/509

5 Trimastuti, W., 64-68

${ }^{6}$ Pradianti, W. (2013). The Use of Slang Words Among Junior High School Students in Everyday Conversation (A Case Study in The Ninth Grade Students of A Junior High School in Bandung). Passage, 1 (1), 87-98

7 Rezeki, T. I., et al. (2019). Semantics Analysis of Slang (SAOS) in Social Media of Millenial Generation. Jurnal Kredo, 3 (1), 36-46
} Jurnal Kopis: Kajian Penelitian dan Pemikiran Komunikasi Penyiaran Islam Volume 03, issue 02, Februari 2021 
are not found in this study are the discussion about the interpretation of meaning and the relationship between data findings and relevant theories. At the beginning, the researcher explained that there was an exploration of the interpretation of the meaning of slang language, but there was no discussion throughout the paper. On the other hand, the theory used is limited to the concept of slang language. There is no study that includes communication theories, because it can be said that research on slang is a component in the communication process.

Meanwhile, in the global realm, there has not been much exploration of the use of slang language. One of the studies that was found was from Izmaylova, et al which discussed the extent of the use of slang language among Russian adolescents. The results obtained show that the origin of many slang language in Russia is taken from English or what is known as anglicism. Teenagers use the word to denote specialization, subject name, in interpersonal relationships, in conversations about various areas of life and leisure. Slang language plays a very important role in the lives of teenagers, their lives cannot be imagined without slang language which not only helps young people to communicate between them, but also facilitates the process of assimilation of new foreign lexicons. One of the factors contributing to expanding and increasing the intensity of the use of slang language is the role of the media through youth programs on television, Internet games, and participation in various sports events ${ }^{8}$. The interesting side of this research is that it is able to explain the genealogy of slang language, how the different interpretations of meaning among adolescents, the benefits of using slang language, and the factors behind the use. But on the other hand, just like previous research, there has been no theoretical study that presents the relationship between theory and phenomena.

Some of the research above serves to show the position as well as the benefits of this research. The salient weakness of some of the research is the lack of variations in the aspects discussed and theoretical studies. The research from Trimastuti for example. He uses sociolinguistic theory to see the social context in the use of slang language. Other aspects such as interpretation of meaning, sources of interpretation, motivation or goals and the resulting impacts are not studied and linked to relevant theories. On the other hand, Pradianti and Rizki, et al only discuss it in terms of how slang language is used, variations in its discussion, application media and purpose of use. For the interpretation of the slang language itself, the impact it has, the source of information from which they understand and get such language and its relation to communication theory has not been discussed yet. Meanwhile in the global realm, research from Ismaylova, et al is also limited to describing the findings obtained. The findings in question include the genealogy or origin of slang language in Russia, the importance or benefits of the language, differences in interpretation among adolescents and the factors underlying the use of slang language. But once again, the theoretical study in this research is not very deep.

8 Izmaylova, G. A., et al. (2017). Linguistic and Social Features of Slang. International Journal of Scientific Study. DOI: 10.17354/ijssSept/2017/016

Jurnal Kopis: Kajian Penelitian dan Pemikiran Komunikasi Penyiaran Islam Volume 03, issue 02, Februari 2021 
From several studies that have been previously described, the position of the research here is to complete the gaps that are not contained in the research before, including presenting various aspects that can be seen from slang language, particularly the word of anjay, starting from how society interprets it, the source of information in obtaining meaning, the use of the word of anjay seen from its social context, motivation or purpose of use and the impact it causes. Then, with these various variations the researcher will relate it to communication theories that play a role in seeing the structure and function of language in society.

So that the output of this paper is a multitheoretical communication framework as an effort to provide a complete and comprehensive theoretical study in seeing various aspects that can be explored from the interpretation and use of slang language. On the other hand, the usefulness of research lies in the many theoretical views that can be used as references in studying the same problem. As for the limitations of the research, because there are so many existing communication theories, it is possible that there are theories that have not been included all of them. However, at least a multitheoretical communication framework like this can provide an overview and theoretical direction as to what is relevant in studying the phenomenon of slang language.

\section{Method}

This study used a qualitative approach with a constructivism paradigm. Based on this approach, researchers chose the case study method because according to Sturman, a case study is a general term for the exploration of an individual, group or phenomenon? Therefore, Starman adds that a case study is a comprehensive description of an individual case and its analysis ${ }^{10}$. The same is the case with this research. The researcher examine comprehensively the activities and interactions between individuals using slang language, reviewing them from various points of view, not only in terms of interpretation, but also sources of information in obtaining meaning, context and impact. In order to be more comprehensive, the researcher tries to link the data findings with relevant theories.

The data collection technique used in-depth interviews, where the sampling technique was based on purposive sampling. The researcher selected several people who knew and had used the word of anjay. The number of informants were 5 people. Because with this amount, the saturated level has been reached. Saturation means that no additional data is found where the researcher can develop the property of a category when he sees similar examples repeatedly, the researcher becomes empirically convinced that a category is saturated ${ }^{11}$.

\section{Result and Discussion}

From the five informants who were interviewed, the researcher got several important points that could be related to communication theory. Some of these points are:

\footnotetext{
9 Starman, A. B. (2013). The Case Study as A Type of Qualitative Research. Journal of Contemporary Educational Studies, 28-43

${ }^{10}$ Starman, A.B., 28-43.

${ }^{11}$ Saunders, B., et al. (2017). Saturation in Qualitative Research: Exploring Its Conceptualization and Operationalization. Quality \& Quantity International Journal of Methodology, 52 (4). DOI: 10.1007/s11135-0170574-8

Jurnal Kopis: Kajian Penelitian dan Pemikiran Komunikasi Penyiaran Islam

Volume 03, issue 02, Februari 2021
} 
a. Interpretation of the meaning of Anjay

The five informants agreed that there was no standard meaning of anjay. It's just that they know from how the word is used, it can have a positive or negative connotation. As a positive connotation, the word of anjay means admiration for something, being surprised, happy and as a sign of intimacy. As for the negative connotation, some mean that this word can be used to disparage other people.

b. Sources of Interpretation of the Meaning of Anjay

Results of Interactions with Others

Several informants said that they could have their own understanding of anjay due to the influence of other people. They said, the lecture of environment or in the world of work, especially in big cities, was the starting point for them to know and understand the word.

\section{Media Impact}

The virality about prohibiting the use of anjay on social media also contributed to other informants to start looking for this word from the media. So from here it is possible to have different interpretations due to different sources and there is no standard meaning in this regard.

c. The Use of Anjay

Social Context: Opponents Talk

The word of anjay was used by informants with their peers. Some added, not only peers, but also friends who have been close or have been friends for longer. In addition, there are those who think, when the interlocutor has one character and personality, even though they are older (not parents), they do not hesitate to use anjay.

Social Context: Regional Culture

The use of anjay requires looking at the social situation and environment. As revealed by the five informants that they used anjay and even knew the word from college or school friends in the city. Interestingly, when they are in a place or area with a narrower coverage and not very modern, the word is never used. According to them, with a different culture, there is a concern that misunderstanding will occur.

d. Motivation for the Use of Anjay

From some informants, their answers regarding the motivation for using anjay are differed. Some said that their motivation was due to their self-existence so they could be more social, when other friends used this word, some informants indirectly admitted that they also used anjay too. There are also those who are motivated by media trends. The virality of anjay on social media, made some informants get to know it and use it more often in their daily lives.

e. The Impact

All informants stated that the use of anjay can strengthen mutual relations. The communication process that took place felt more fluid and less rigid. Although some say that anjay can be interpreted to denigrate another person, in reality when the word is used in that context, it does not cause conflict. Their relationship is getting closer. 
From some of the data findings obtained based on the results of in-depth interviews with the five informants, the concept of slang language as stated earlier is indeed relevant to seeing this phenomenon, where this language is an informal language used to strengthen identity and increase cohesiveness in groups. As stated by the five informants above, by using anjay they agreed that personal relationships became closer and more intimate. In addition, through one of the four points of identification of slang as stated by Dumas and Lighter, the use of slang language depends on the social context, with whom we speak and in what environment ${ }^{12}$. It is the same as the statement of the informants that when they want to use the word of anjay, they need to look at the situation and condition. Because when it is misplaced, the interpretation that arises can be wrong and lead to misunderstanding.

Meanwhile, the motivation for its use can be related to the function of slang language as proposed by Rachmijati as a means of communicating feelings and thoughts and sharing emotional experiences ${ }^{13}$. The informants said that anjay was an expression of admiration for something or it could have a negative connotation, namely to humiliate others. On the other hand, not only linking conceptualization of slang language with data findings, this study also looks at the relationship between research results and relevant communication theory. This relationship can be summarized in the following table:

Table 1: Multitheoretical Communication Framework of Anjay

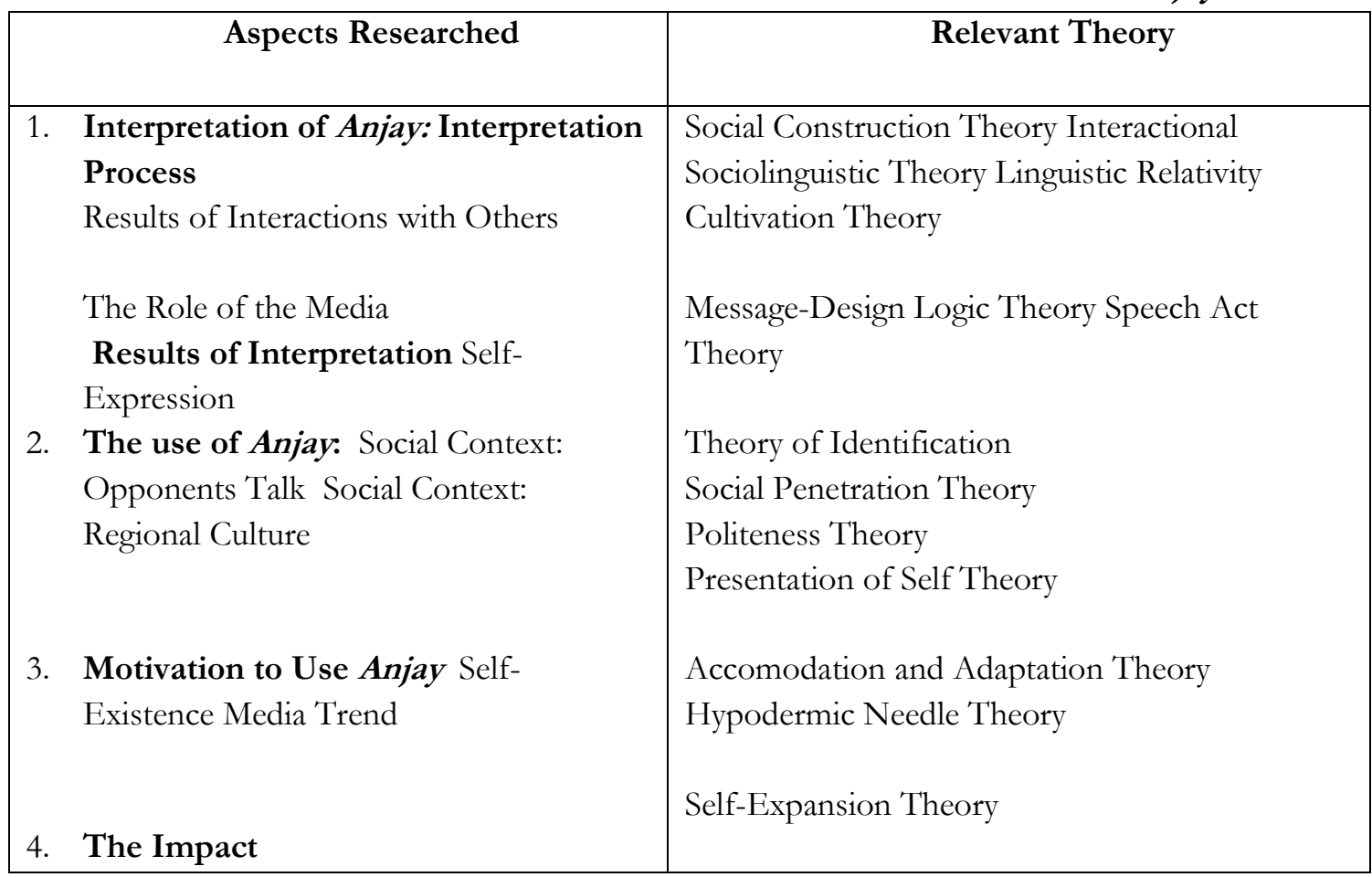

12 Eble, C. (1996). Slang \& Sociability. USA: The University of North Carolina Press

13 Rachmijati, C. (2015). An Analysis of The Slang Language Used in The Movie "Juno". ELTIN Journal, 3 (2), 97-105. Retrieved from http://e-journal.stkipsiliwangi.ac.id/index.php/eltin/article/view/126/115

Jurnal Kopis: Kajian Penelitian dan Pemikiran Komunikasi Penyiaran Islam

Volume 03, issue 02, Februari 2021 


\section{Interpretation Process of Anjay Interpretation Process: Results of Interactions with Others Social Construction Theory}

According to Littlejohn \& Foss, ocial construction theory discusses the process by which people collectively build their understanding of the world ${ }^{14}$. There are three elements in social construction theory according to Littlejohn \& Foss, namely the social, construction and reality. The social, emphasizes the assumption that social reality requires interaction between humans. Construction is social in the sense that it requires collaborative rather than individual effort. Whatever is in the social world occurs as a result of the words and / or actions of people who talk and interact together ${ }^{15}$.

The second component is construction. Littlejohn \& Foss stated that the essence of social construction is the verb to build, which means to build something, make something, or make something happen that did not exist before. Based on a statement from James Carey that social construction theory is based on three stages, namely construction or building something that did not exist before, maintaining, people need to actively maintain certain social constructions if they want to survive, because if it is no longer relevant, it will be ignored and thus dissolved. And the third is repair and change, social actors need to periodically improve their construction because aspects may be accidentally forgotten or deliberately changed over time ${ }^{16}$.

Apart from the social and construction, the final component, namely reality, creates meaning in the physical world as well as meaning in social reality without prior physical existence. That is, social actors create various kinds of texts, either verbal or visual as well as an understanding of this ignorance and other social productions ${ }^{17}$. In realizing these three components, one of the keys to realizing it is language. As stated by Littlejohn \& Foss, in social construction theory, the language code of each person during the interaction helps to construct a self that is relevant to a certain moment. In this theory, the self is not single but diverse, so there is always a choice of self that is relevant in accordance with the context ${ }^{18}$.

\section{Interactional Sociolinguistic Theory}

According to Littlejohn \& Foss, interactional sociolinguistic theory is specifically concerned with how the background knowledge and experiences of social actors function as resources in interactions ${ }^{19}$. In other words, according to them, this theory focuses on how interpretations and meanings are constructed by the interactants and on how past experiences affect current understanding. One important implication, interactional sociolinguistic theory explains why people from different cultural backgrounds so often

\footnotetext{
${ }^{14}$ Littlejohn, S. W. \& Foss, K. A. (Eds.). (2009). Encyclopedia of Communication Theory. USA: SAGE, h. 891 896

${ }^{15}$ Littlejohn, S. W. \& Foss, K. A. (Eds.), h. 892

${ }^{16}$ Littlejohn, S. W. \& Foss, K. A. (Eds.), h. 892

${ }^{17}$ Littlejohn, S. W. \& Foss, K. A. (Eds.), h. 893

${ }^{18}$ Littlejohn, S. W. \& Foss, K. A. (Eds.),h. 893

${ }^{19}$ Littlejohn, S. W. \& Foss, K. A. (Eds.), h. 903
} 
Havelaar difficulty communicating. For example, the intonation pattern of a speech. The same words have very different meanings depending on how they are pronounced ${ }^{20}$.

\section{Linguistic Relativity}

According to the Whorfian hypothesis, the linguistic relativity theory emphasizes that the language structure of a culture determines the habits of thought behavior in that culture. Even according to Sapir,

Humans do not live in the objective world alone, are not alone in the world of social activity as it is usually understood, but are very dependent on certain languages which have become a medium of expression for their society .... The fact is that the "real world" is largely unconsciously built on habits. group language.... We see and hear and vice versa experience it mostly as we do because the language habits of our community influence certain interpretive choices ${ }^{21}$

\section{The Relationship between Theory and The Interpretation of Anjay}

From the three theories above, the outline that can be understood is that the interpretation of anjay is the result of individual social construction in their interactions with other people. Through social construction theory, for example. There it has been explained that whatever exists in the social world occurs as a result of interactions between humans. In this interaction, they construct something from what originally did not exist into something that has meaning. The word of anjay starting from nothing can be a language that used to express a person's expression. Only after the word of anjay became meaningful linguistic theory of relativity and interactional sociolinguistics could be applied.

According to the linguistic relativity theory, human interpretation of a language is determined by the language habits of the community. When the word of anjay has become something meaningful, according to the accounts of several informants, they often hear this word in modern urban areas. The community there introduced them to the word of anjay as an expression of admiration for something. So that in an urban environment, this word has become a common word and tends not to have a negative connotation, because the habits that are formed have taught such things. It's different when they say this among villagers. Because the people there are not accustomed to using words like that, the interpretation that appears according to them can be interpreted negatively. Therefore, relativity like this is also read through the interactional sociolinguistic theory which explains that the meaning of a language may differ depending on the experiences of the interactants, including those related to their respective cultures.

\section{The Process of Interpretation: The Role of the Media Cultivation Theory}

Historically, this theory refers to television media which has a role in sharing perspectives about the world. According to Gerbner and his friends, the impact of television is pervasive in our culture, namely cultivating certain perspectives in each segment of society. Researchers believe that television is a homogenizing agent that

${ }^{20}$ Littlejohn, S. W. \& Foss, K. A. (Eds.), h. 903

${ }^{21}$ Littlejohn, S. W., et al. (2017). Theories of Human Communication Eleventh Edition. USA: Waveland Press, h. 116

Jurnal Kopis: Kajian Penelitian dan Pemikiran Komunikasi Penyiaran Islam

Volume 03, issue 02, Februari 2021 
cultivates a special culture ${ }^{22}$. Although this theory is intended for television, in reality conventional mass communication theories can also be brought into the realm of new media. Social media, with its easier and more interesting nature, from its reach, broadcast time to interactive features in it, can also be related to how the cultivation theory works.

\section{The Relationship between Theory and the Role of the Media}

Its real-time nature by presenting the hottest topics as well as those that are of interest to the public makes information easily absorbed when presented via social media. Like anjay itself. When Lutfi Agizal said that this word had a negative connotation until the issuance of the prohibition, the community searched for the definition of anjay. This was revealed by some informants. Although not the result of interactions from other people, they admit that they know and understand this word after they browse information through internet. Therefore, from these findings, it can be said that mass media, especially new media, can instill or cultivate certain perspectives to individuals or groups about something.

\section{Interpretation of Anjay as A Form of Self-Expression Message-Design Logic Theory}

This theory stems from Barbara O'Keefe's thinking that there are different ways of approaching messages, and that people use different logic in deciding what to say to others depending on the situation. He uses the term message design logic to describe the thought process behind the message created $^{23}$. There are three logics in this theory, namely expressive logic, conventional logic, and rhetorical logic. From the three logics above, what is used in this paper is the expressive logic. Because based on the research results, the word of anjay is a form of someone's expression about something. Like the concept of expressive logic itself, what O'Keefe calls the communication of feelings and thoughts. Messaging in this fashion is open and reactive, with little attention paid to the needs or wants of others. In the language of constructivism, expressive logic is more self-centered than peoplecentered $^{24}$.

\section{Speech-Act Theory}

Speech-act theory is associated with John Searle who is interested in how we achieve things with words. This theory identifies what is needed to make successful adjudication - in order for intentions to be understood. So, knowing words alone is not enough, knowing what to achieve using words is equally important ${ }^{25}$. From this definition, there are four forms of speech-act theory, namely an utterance act, propositional act, illocutionary act and perlocutionary act. Littlejohn, et al explain that for an utterance act, you produce a pronunciation action, a simple pronunciation of the words in a sentence.

\footnotetext{
${ }^{22}$ Littlejohn, S. W., et al. h. 159

${ }^{23}$ Littlejohn, S. W., et al. h. 130

${ }^{24}$ Littlejohn, S. W., et al. h. 130

${ }^{25}$ Littlejohn, S. W., et al.h. 121
} 
Second, you affirm something about the world, or take a propositional action. In other words, you say something that you believe is true or you try to get someone else to believe it is true. Third, you fulfill an intention, which is called an illocutionary act. Your main concern is that the listener understands the point - whether it's a promise, invitation, or request. Lastly, there is a perlocution action in which the speaker expects the listener to not only understand the intention but also to $\mathrm{act}^{26}$.

Of the four forms, the most relevant to the context of a person's interpretation about anjay is illocutionary action, in which there are five types, namely assertive, directives, comissives, expressives and declaration. Just like the previous message-design logic theory, anjay is interpreted as a form of one's expression about something. Thus, the expressives contained in this speech-act theory also confirm this. According to Littlejohn, et al, expressives are actions that communicate several aspects of a speaker's psychological state, such as thanking, congratulating, apologizing, comforting and welcoming ${ }^{27}$. This psychological condition can be expressed through anjay which according to some informants contains a sense of admiration, some interpret it as a negative word to demean others.

\section{Usage of Anjay}

\section{a. Social Context: Interlocutors Theory of Identification}

According to Burke, language serves as a vehicle for action. Due to the social need for people to cooperate in their actions, language shapes behavior ${ }^{28}$. Thus, because of these needs, languages can unite or divide. When symbols unite people into a common way of understanding, identification is said to occur. Conversely, splits can also occur; language can enhance identification, or it can increase separation and schism.

There are three sources of identification according to Burke. Littlejohn \& Foss explained that the three sources include identification materials from goods, possessions, and something that has similarities such as the same type of car or similar taste in clothing. There is also idealistic identification, which is the identification of common ideas, attitudes, feelings and values such as being a member of a church or a political party. Finally, there is formal identification. This identification stems from the arrangement, form, or organization of an event in which both parties participate such as attending a trade show ${ }^{29}$.

\section{Social Penetration Theory}

Social penetration theory is used to identify the process of increasing self-disclosure and intimacy in a relationship ${ }^{30}$. Littlejohn \& Foss explain this theory with the parable of a ball. Inside this ball there is everything that can be known about a person, experiences, influences, knowledge, attitudes, ideas, thoughts and actions. This information goes around the core or center of the ball. Things that are closest to the center of the ball are those that are furthest from the outside, farthest from what other people can see or detect. This is the most personal aspect of a person's identity. When moving outside the circle this

${ }^{26}$ Littlejohn, S. W., et al. h.121-122

${ }^{27}$ Littlejohn, S. W., et al. h.122

${ }^{28}$ Littlejohn, S. W., et al. h. 127

${ }^{29}$ Littlejohn, S. W., et al. h. 127-128

${ }^{30}$ Littlejohn, S. W. \& Foss, K. A. (2011). Theories of Human Communication Tenth Edition. USA: Waveland Press. h. 235

Jurnal Kopis: Kajian Penelitian dan Pemikiran Komunikasi Penyiaran Islam

Volume 03, issue 02, Februari 2021 
information will be closer to what others can $\operatorname{see}^{31}$. So in other words, when someone wants to get to know someone else, he has to "penetrate" the ball. A person can learn various kinds of things about other people or can learn more detailed or deep information. This is where the identification process runs. When someone tries to find and get to know other people's personalities by penetrating the ball, then he will increasingly find whether there are similarities between them or not. When not, then the relationship will not develop, and vice versa.

\section{The Relationship between Theory and The Use of Anjay in Terms of Interlocutors}

Based on the explanation above, this identification theory can be applied in the selection of communicants by communicators, especially from the concept of one source of identification, namely idealistic identification. In this context, before merging into a unit, the communicator identifies with others whether there are similarities in ideas, attitudes, feelings and values. When the identification is complete, it is possible to choose words freely. Not only from theory of identification, social penetration theory also emphasizes the same thing. In a relationship, a person needs to know other people first to determine what their future attitude will be, including language problems. How the nature and character of others need to be considered in choosing a word. Such as the problem of using anjay. Several informants said that in using this word needed to identify the person to whom they spoke. Are they familiar before or do they share common traits. When there are similarities, they easily use slang words. If not, then they tend to adjust the language selection based on the level of familiarity or the nature of the interlocutor.

\section{a. Social Context: Local Culture Politeness Theory}

This theory was developed by Penelope Brown and Stephen Levinson. Littlejohn, et al stated that in everyday life we design messages that protect faces and achieve other goals as well. They also believe that modesty is often the goal because it is a universal cultural value $^{32}$. Different cultures have different levels of politeness, different ways of being polite, but everyone has a need to be respected and protected, which they call a facial need. There are two facial needs referred to by Brown and Levinson, namely positive and negative facial needs. The positive face need is the desire to be appreciated, approved, liked and respected, while the negative face need is the desire to be free from coercion or interference ${ }^{33}$. Therefore, seeing the other person is important in this context. Because there are various levels of politeness. As Littlejohn explained, the way to talk to older siblings and parents is of course different. When talking to older siblings of the same age, you just need to be a little polite. However, when it comes to parents, then making any requests must be even more polite.

\section{Presentation of Self Theory}

\footnotetext{
${ }^{31}$ Littlejohn, S. W. \& Foss, K. A. h. 236

${ }^{32}$ Littlejohn, S. W., et al. (2017). Theories of Human Communication Eleventh Edition. USA: Waveland Press. H. 133

${ }^{33}$ Littlejohn, S. W., et al. h. 134
} 
Littlejohn, et al explain that this theory refers to Erving Goffman's thoughts who use theatrical metaphors to explain how communicators present themselves. Everyday situations can be seen as a stage, and society is the actor who uses appearance to impress the audience. When entering a situation, everyone will ask "What's going on here?" The answers you get from these questions will shape the definition of the situation. From this definition, someone will determine how to position oneself, what to say and how to $\mathrm{act}^{34}$

\section{The Relationship between Theory and the Use of Anjay in Terms of Local Culture}

When it comes to the interlocutor, the discussion that is raised is how a person identifies the character of the interlocutor. Meanwhile, in terms of regional culture, the discussion is more general, how the culture in cities and villages impacts a person's behavior. In the politeness theory it is explained, different cultures, so the level of politeness is also different. Same is the case with presentation of self theory. This theory looks at how each situation is different. With these differences, a person is required to adjust where he is. What to say, how to position oneself and how to act depend on the surrounding social context. All informants said that they used anjay more when studying or working in urban areas. When they returned to their hometowns, they did not dare to use this word. In areas that are quite modern, because the association tends to be free, slang language is indeed widely used. It's different when in the village. The use of anjay tends to be considered taboo.

\section{Motivation to Use Anjay}

\section{a. Existence of Self}

\section{Accomodation and Adaptation Theory}

In accommodation theory recognizes normative demands which examine how people change the level of their language formality as a function of the social context in which they are located. In other words, we should speak very softly and respectfully here, but we can be more boisterous and relaxed there ${ }^{35}$. It is also emphasized by Littlejohn \& Foss that accommodation theory is one of the most influential theories of communication behavior. Formulated by Howard Giles and his colleagues, accommodation theory explains how and why we adapt our communication behavior to the actions of others. In doing so, according to Giles and his colleagues, there are two types of action, namely convergence or unite and divergence or moving away ${ }^{36}$.

After the accommodation stage is completed, the next step is the adaptation process. According to Littlejohn \& Foss, in most interactions, a person's behavior will change as well as the partner's behavior - this is called reciprocal influence. The mutual influence can be profound and in most situations, far greater than any prior planning ${ }^{37}$.

The Relationship between Theory and the Motivation of Using Anjay for SelfExistence

\footnotetext{
${ }^{34}$ Littlejohn, S. W., et al. h. 77

${ }^{35}$ Littlejohn, S. W. \& Foss, K. A. (2011). Theories of Human Communication Tenth Edition. USA: Waveland Press. H. 183

${ }^{36}$ Littlejohn, S. W. \& Foss, K. A. h. 183

${ }^{37}$ Littlejohn, S. W. \& Foss, K. A. h. 186

Jurnal Kopis: Kajian Penelitian dan Pemikiran Komunikasi Penyiaran Islam

Volume 03, issue 02, Februari 2021
} 
The self-existence referred to here is related to the answers of each informant who agrees that they use the word so that he can immerse himself in existing communication with peers. In other words, they try to make accommodation and adaptation efforts in order to be accepted by their social environment. Take accommodation theory for example. There it is explained that how a person's actions can change according to the actions of others. Likewise with adaptation theory. In most interactions a person's behavior will change along with changes in other people's behavior. The informants explained that they initially did not know about anjay. It's just that, when they work in a big city or study there, they start to recognize this word and use it as everyday language due to social influences. They are carried away as a form of accommodation and adaptation with their friends so that their existence is recognized.

b. Media Trend

\section{Hypodermic Needle Theory}

Littlejohn \& Foss explain that according to this theory, a mediated message can be seen as something that is injected under the recipient's skin. The media effect is thus seen as a direct and powerful effect. This idea assumes that individuals in modern society are lonely, vulnerable and easily manipulated. The idea of a powerless audience continues, albeit in a less crude form, to influence understanding of the mediated persuasion process, as many advertisements and public information campaigns are still based on strategies to change the knowledge, attitudes and behavior of individuals by exposing that content repeatedly ${ }^{38}$.

\section{The Relationship between Theory and Trends in Media Coverage of Anjay}

Even though the hypodermic needle theory was born during the Hitler government which carried out propaganda via radio, in reality this theory is still relevant if it is related to current phenomena. As explained by Littlejohn \& Foss above that even though it is not carried out in a form that is too harsh, many advertisements and public information campaigns are repeatedly exposed to change the knowledge, attitudes and behavior of individuals ${ }^{39}$. It's the same with the current condition. Even though it is not as rude as the Nazi era, social media provides the facility of displaying content repeatedly and this is one of the reasons that allows someone to change their mindset and behavior. Likewise with anjay content. Since it went viral on social media about the opinion of someone who thought this word had a negative connotation, a lot of content has emerged regarding it, both pro and contra news or jokes. With this virality, some informants finally started to know and use anjay.

\section{The Impact from The Use of Anjay \\ Self-Expansion Theory}

In maintaining good relations, Laura Stafford and Dan Canary revealed that there are five foundations, namely positivity, openness, assurances, sharing tasks and social

\footnotetext{
${ }^{38}$ Littlejohn, S. W. \& Foss, K. A. (Eds.). (2009). Encyclopedia of Communication Theory. USA: SAGE, h. 64

${ }^{39}$ Littlejohn, S. W. \& Foss, K. A. (Eds.), h. 64
} 
networks. From the five foundations, various theories emerge, including equity theory, uncertainty management theory and self-expansion theory ${ }^{40}$. Among the three theories, is the self-expansion theory which can explain the impact of the use of anjay on interpersonal relationships. This theory suggests that relational partners are goal-oriented communal. Partners are motivated to develop themselves by disclosing information, sharing resources and developing a common identity.

\section{The Relationship between The Theory and The Impact Arising from The use of Anjay}

The impact of using anjay is that each individual involved in a relationship becomes increasingly familiar. That way, when associated with self-expansion theory, each individual uses the word solely for communal purposes. They do not take material advantage or to eliminate uncertainty, but rather communality or association based on the principle of equality. So that it is not half-hearted, with the word of anjay, according to all informants it can increase this communality, everyone is getting closer and not feeling awkward with each other.

\section{Conclutions}

From the results of the data findings indicate that slang language, especially anjay, can be explored from various points of view and the data findings show that the statements of the informants are relevant to the concept of slang language, both in terms of function or role and actualization.

The first aspect to look at relates to the interpretation of the meaning of anjay. The informants explained that anjay has different interpretations of meaning depending on the source of the information. In addition, the social context with whom we speak and local culture also play a role in the use of the word anjay. The character of other people and the prevailing social norms can be a reference for how to place oneself and organize words. Each person's motivation is also different, whether it is to show one's existence in the middle of social interactions or just to follow media trends. And finally the resulting impact is relevant to the concept of slang itself, that the use of this word can bring positive results in interpersonal relationships. Each individual can be more familiar with each other and there are no boundaries between them. Meanwhile, in terms of theory, at a time when there were not many researches that deepened theoretical studies, several previous studies were known to only describe data findings, relate them to the concept of slang itself and only refer to one theory to generalize in general, in this case there are various theories. relevant communication to be associated with the phenomenon. Not only one theory, but based on the aspects studied, it can be studied according to different theories. However, for the recommendations of further research, other researchers can further broaden the scope of theory, so that it is not limited to communication science. There are many disciplines with their respective theories, for example psychology, anthropology and all kinds of things that can study the phenomenon of slang in society.

${ }^{40}$ Littlejohn, S. W., et al. (2017). Theories of Human Communication Eleventh Edition. USA: Waveland Press, h. 253

Jurnal Kopis: Kajian Penelitian dan Pemikiran Komunikasi Penyiaran Islam

Volume 03, issue 02, Februari 2021 


\section{Reference}

Abas, D. (2020, September 02). Lutfi Agizal Kaget Dibujat Warganet karena Pelopori Larangan Kata "Anjay". Medcom. Retrieved from https://m.medcom.id/hiburan/selebritas/yKXAaZDN-lutfi-agizal-kaget-dihujatkarena-pelopori-larangan-kata-anjay.

Azanella, L. A. (2020, August 31). Larangan Penggunaan “Anjay”, Reaksi Netizen, dan Kata Abli Bahasa. Kompas. Retrieved from

https://www.kompas.com/tren/read/2020/08/31/081829965/larangan-penggunaananjay-reaksi-netizen-dan-kata-ahli-bahasa?page=all\#page2

Eble, C. (1996). Slang \& Sociability. USA: The University of North Carolina Press

Izmaylova, G. A., et al. (2017). Linguistic and Social Features of Slang. International Journal of Scientific Study. DOI: 10.17354/ijssSept/2017/016

Littlejohn, S. W. \& Foss, K. A. (Eds.). (2009). Encyclopedia of Communication Theory. USA: SAGE.

Littlejohn, S. W. \& Foss, K. A. (2011). Theories of Human Communication Tenth Edition. USA: Waveland Press

Littlejohn, S. W., et al. (2017). Theories of Human Communication Eleventh Edition. USA: Waveland Press

Pradianti, W. (2013). The Use of Slang Words Among Junior High School Students in Everyday Conversation (A Case Study in The Ninth Grade Students of A Junior High School in Bandung). Passage, 1 (1), 87-98.

Rachmijati, C. (2015). An Analysis of The Slang Language Used in The Movie "Juno". ELTIN Journal, 3 (2), 97-105. Retrieved from http://e-journal.stkipsiliwangi.ac.id/index.php/eltin/article/view/126/115

Rezeki, T. I., et al. (2019). Semantics Analysis of Slang (SAOS) in Social Media of Millenial Generation. Jurnal Kredo, 3 (1), 36-46.

Saunders, B., et al. (2017). Saturation in Qualitative Research: Exploring Its Conceptualization and Operationalization. Quality \& Quantity International Journal of Methodology, 52 (4). DOI: $10.1007 / \mathrm{s} 11135-017-0574-8$

Starman, A. B. (2013). The Case Study as A Type of Qualitative Research. Journal of Contemporary Educational Studies, 28-43. 
Trimastuti, W. (2017). An Analysis of Slang Words Used in Social Media. Jurnal Dimensi Pendidikan dan Pembelajaran, 5 (2), 64-68. Retrieved from http://journal.umpo.ac.id/index.php/dimensi/article/view/497/509

Umam, C \& Purnianda, Y. (2016). Slang Words and Their Morphological Processes on Jeff Kinney's Diary of A Wimpy Kid. Realita, 14 (2), 175-186. 